\title{
Drama Temelli Probleme Dayalı Öğrenme Yaklaşımının İlkokul Öğrencilerinin Empati Beceri Düzeyleri Üzerine Etkisi
}

\section{Effects of Problem-Based Learning Utilized with Drama Applications on Primary School Pupils' Empathy Skill Levels}

\author{
Ogün ÇAKIR * (D) Zeliha Nurdan BAYSAL ${ }^{* *}$ \\ Funda İNAN-YILDIZ ***
}

\begin{abstract}
The purpose of this study is to investigate the effects of Problem-Based Learning (PBL) utilized with drama applications in which the problem state was evoked on primary school pupils' empathy skill levels. Pretestposttest control-group design was utilized through the research which was applied on two groups each consisting of $243^{\text {rd }}$ graders in Istanbul. Data collection was conducted with "Scale of Empathy for Children". PBL process utilized with drama applications in which the problem state was evoked was conducted on experimental group and none on control group. Two of researchers prepared study plan for experimental group and, this plan was applied for three weeks. Shapiro-Wilk normality test, independent-samples t-test and paired-samples t-test were used for data analysis. Findings of the research show that empathy skill levels of the pupils in experimental group were significantly higher than of control group and that PBL utilized with drama applications was effective on increasing primary school pupils' empathy skill levels.
\end{abstract}

Keywords: drama, empathy, primary school, problem-based learning

ÖZ: $\mathrm{Bu}$ araştırmanın amacı, drama ile problemin hissettirildiği Probleme Dayalı Öğrenme ( $\left.\mathrm{P}_{\mathrm{b}} \mathrm{DÖ}\right)$ yaklaşımının öğrencilerin empati beceri düzeyleri üzerine etkisini incelemektir. Öntest-sontest kontrol gruplu yarı deneysel modelin kullanıldığı araştırma kapsamında İstanbul ilinde ilkokul üçüncü sınıfa devam eden 24'er öğrenciden oluşan iki grup üzerinde çalışılmıştır. Veri toplama aracı olarak "Çocuklar İçin Empati Ölçeği (ÇİEÖ)" kullanılmıştır. Deney grubunda drama ile problemin hissettirildiği $\mathrm{P}_{\mathrm{b}} \mathrm{DÖ}$ yaklaşımı uygulanırken, kontrol grubunda herhangi bir deneysel uygulama yapılmamıştır. Deney grubunun çalışma planı araştırmacılar tarafından hazırlanmış ve üç hafta boyunca deney grubu sınıfında uygulanmıştır. Elde edilen verilerin analizinde Shapiro-Wilk normallik testi, bağımlı gruplar ttesti ve bağımsız gruplar t-testi kullanılmıştır. Araştırmanın bulgularına göre; $\mathrm{P}_{\mathrm{b}} \mathrm{DÖ}$ yaklaşımının uygulandığı deney grubu öğrencilerinin kontrol grubuna kıyasla empati beceri düzeylerinin geliştiği, drama temelli $\mathrm{P}_{\mathrm{b}} \mathrm{DÖ}$ yaklaşımının ilkokul öğrencilerinin empati beceri düzeylerini geliştirmede etkili olduğu anlaşılmıştır.

Anahtar kelimeler: drama, empathy, primary school, problem-based learning

\footnotetext{
Corresponding Author: PhD Student, Marmara University, İstanbul, Turkey, oguncakir@marun.edu.tr, https://orcid.org/0000-0003-4423-4821

** Assoc. Prof. Dr., Marmara University, İstanbul, Turkey, znbaysal@ marmara.edu.tr, https://orcid.org/0000-00023548-1217

**** PhD Student, Marmara University, İstanbul, Turkey, inanyildizfunda@gmail.com, https://orcid.org/0000-00034929-2254
}

\section{Citation Information}

Çakır, O., Baysal, Z. N., \& İnan-Yıldız, F. (2019). Drama temelli probleme dayalı öğrenme yaklaşımının ilkokul öğrencilerinin empati beceri düzeyleri üzerine etkisi. Kuramsal Eğitimbilim Dergisi [Journal of Theoretical Educational Science], 12(3), 1044-1066. 


\section{Giriş}

Eğitim, bireyin davranışlarını topluma daha iyi uyum sağlayabilmesi ve mutlu yaşaması için düzenleyebilmesinin en önemli aracıdır. Eğitim vasıtasıyla bireyin kendi duygularını anlayabilmesi, tanımlayabilmesi, anlatabilmesi ve kontrolünü sağlayabilmesi kadar diğerlerinin duygularına da duyarlılık geliştirebilmesi yani empati kurabilmesi oldukça önemlidir.

Empati becerisi, bireyin kendisini bir başkasının yerine koyması suretiyle herkesin birbirine karşı eşit sorumluluklar taşıdığı, adaletli bir ortak yaşamı deneyimlemesi sürecidir (Kohlberg, 1975). Barışçıl ve insancıl bir toplumsal yaşamın köklenebilmesi, bireylerin diğerlerinin duygu ve düşüncelerini anlayıp yorumlayabilmesi ile mümkündür. Bu becerilerin çocukluğun ilk yıllarından başlayarak kazandırılması, geleceğin yetişkin bireylerinin sağlıklı toplumsal ilişkiler kurabilmelerini sağlayacak bir eğitim anlayışının benimsenmesine bağlıdır. Bu bakımdan insancıl bir eğitim anlayışı; saygıyı, şefkati, empatiyi ve hem başka bireylerin hem de başka canlıların varlığına yönelik olumlayıcı bir algıyı destekler nitelikte olmalıdır (Nicoll, Trifone, \& Samuels, 2008), çünkü insanlar topluluklar içerisinde yaşayan varlıklardır ve toplumsal denge ancak bireylerin toplum ile sağlıklı düşünsel ve duygusal ortaklıklar kurabilmesi ile mümkündür.

Genel olarak empatinin gerek rol oynama gerekse bir başkasının duygularını anlayabilmek için "o kişiymiş gibi" davranma yoluyla öğretilebilecek yahut geliştirilebilecek bir beceri olduğu kabul edilmektedir (Feshbach \& Feshbach, 2009; Roth-Hanania, Davidov, \& Zahn-Waxler, 2011). Özellikle ilköğretim düzeyinde bilişsel ve sosyal becerilerin geliştirilmesi bakımından programlarda eleştirel düşünmeyi ve empatiyi esas alan bireyler arası duygu ilişkilerine yer verilmesi önemlidir (Ampuero, Miranda, \& Goyen, 2015; Verducci, 2000). Genel olarak drama uygulamaları yaşant1 odaklı olması ve katılımcıların rolünü oynadıkları kişilerin duygularını hissederek diğer katılımcılarla etkileşim halinde olmalarını sağlaması nedeniyle empati becerisinin geliştirilmesi bakımından oldukça etkilidir (Adıgüzel, 2018). Bu yönüyle de empati, ilkokul Hayat Bilgisi ve Sosyal Bilgiler derslerinde bir öğretim yöntemi olarak kullanılmak suretiyle geliştirilebilecek bir beceri olarak karşımıza çıkmakta ve öğretmenler tarafından ilköğretim düzeyinde, özellikle değerler eğitimi süreçlerinde faydalanılmaktadır (Akpınar \& Özdaş, 2013; Kabapınar, 2012).

İlköğretim düzeyinde empati becerisinin kullanımına yahut geliştirilmesine yönelik yapılan çeşitli araştırmalar, empatinin eğitimsel süreçlerde pek çok açıdan belirleyici rol oynadığını ortaya koymaktadır. Söz konusu araştırmalarda, öğrencilerin okula devamlılıklarının empati düzeyleri ile ilişkili olduğu (Salı, 2012); empati becerisini geliştirmeye yönelik çalışmaların okullarda akran zorbalığını önlemede etkili olabileceği (Good, Fox, \& Coffen, 2011; İnan, 2005; Siyez \& Kaya, 2011; Şahin, 2012) ve empati beceri düzeyinin aile içi iletişimin niteliği ile ilişkili olduğu (Kabapınar, Canpolat, Yarar, \& Karaday1, 2016; Yüksel, 2009) anlaşılmaktadır. Genel olarak bakıldığında araştırmalar empati becerisinin toplumla uyumlu bir birey olmada kritik bir öneme sahip olduğunu ortaya koymaktadır.

Empati becerisinin çeşitli model ve yöntemlerle geliştirilebilmesi mümkündür. Günümüz yapılandırmacı eğitim anlayışı perspektifinden bakıldığında öğrenciyi merkeze alan, işbirlikli, iletişim odaklı ve farklı öğretim stillerini işe koşan stratejilerin kullanılmasının faydaları kabul edilmektedir. Probleme dayalı öğrenme ( $\left.\mathrm{P}_{b} \mathrm{DÖ}\right)$ 
yaklaşımı da bu stratejilerin bir parçası olarak yapılandırmacı eğitim anlayışı çerçevesinde empati becerilerinin geliştirilmesine yönelik yapılabilecek uygulamalar için oldukça uygun bir zemin sağlamaktadır.

$\mathrm{P}_{\mathrm{b}} \mathrm{DÖ}$ yaklaşımı John Dewey'nin yaşayarak öğrenme anlayışına dayanan bir öğrenme modelidir. $\mathrm{Bu}$ modelde öğretmenler, öğrencilere problem çözme becerileri kazandırmak ve onları cesaretlendirmek için çeşitli problem durumları oluşturur ve uygun öğrenme ortamı sağlarlar (Karakuş, 2006; Taşkesenligil, Şenocak, \& Sözbilir, 2008). $\mathrm{P}_{\mathrm{b}} \mathrm{DÖ}$ öğrenciyi merkeze alan, küçük çalışma gruplarında gerçekleşen, öğretmenlerin kılavuz ve sağlayıcılık görevi üstlendikleri, problem durumunun kendisinin öğrenmeye yönelik motivasyonu sağladığı, öğrencilerin yeni bilgiler edinme süreçlerinde kendi kendilerini yönlendirdikleri bir anlayışa işaret eder (Borrows, 1996; Çetin, 2011). Bu yaklaşım uyarınca, problemli bir durumla başa çıkma yolları derslerdeki konular aracılığıyla uygulamalı etkinlikler çerçevesinde adım adım öğrenciye kazandırılmaya çalışılır (Aykaç, 2005). Bu anlamda $\mathrm{P}_{\mathrm{b}} \mathrm{DÖ}$ ardışık işlevli şu aşamalardan oluşur (Gijselaers, 1995; Kaptan \& Korkmaz, 2001; Schmidt, 1983; Schultz \& Christensen, 2004):

1. Problemin farkına varılması

2. Problemin doğru biçimde açıklanması

3. Problemi çözmek için gereken bilgilerin belirlenmesi

4. Bilgi toplamak için kullanılabilecek kaynakların belirlenmesi

5. Olası çözümlerin oluşturulması

6. Çözümlerin irdelenmesi

7. Çözümün ortaya konması

$\mathrm{P}_{\mathrm{b}} \mathrm{DÖ}$ yaklaşımıyla basamakları ifade edilen bu süreçte öncelikle problemin/problem durumunun belirlenmesi ve kurgulanması önem taşımaktadır. Öğrenme sürecine kılavuzluk edecek problemin esnek düşünmeyi sağlayıcı, karmaşık, çok yönlü çözüm önerileri gerektirecek, araştırma ve sorgulamaya yöneltici ve yaşamın içinden olması gerekmektedir (Hmelo-Silver, 2004; Kuštrin, 2005; Savery, 2006). Bu süreçte öğrenciler, yaşamın içinden problem durumlarıyla karşılaşır, durumu anlamlandırmaya çalışırken ön bilgi ve deneyimlerini kullanır, araştırmalar yapar ve yeni öğrenmelerini sürekli olarak çalışma gruplarında tartışır ve paylaşırlar (Akpınar \& Ergin, 2005). Öğrenciler birer ekip olarak neyi öğrenmeye ihtiyaçlarının olduğuna, edindikleri bilgiyi nerede ve nasıl kullanacaklarına karar vererek bilgilerini işlevsel hale getirirler (Cantürk-Günhan \& Başer, 2009a). Yaşamın içinden seçilen söz konusu problem durumu veya senaryoları karikatür, pantomim, drama, görsel sunu gibi farklı materyal ve tekniklerin kullanılmasıyla oluşturulabilir. Bu noktada önemli olan husus, öğrencilerin problem durumunu sahiplenerek, çözüm sürecinde en etkin olabilecekleri seçeneği belirlemektir (Baysal, 2005). Belirlenen problem durumunun çözümüne ulaşmada öğrencilerin farklı perspektiflerden bakış açılarını deneyimlemeleri, esnek ve yaratıcı düşünme becerileri edinmede önemli olduğu kadar empati becerilerinin işe koşulup geliştirilmesinde de önem taşımaktadır.

İlkokul düzeyinde, küçük yaş grupları dikkate alındığında problemin hissedilmesi, ortaya konması ve sahiplenilmesi basamağında drama tekniğinden yararlanılması uygun ve verimli görünmektedir. Drama çalışmalarında bireylerin bir 
yaşantıyı veya olguyu önceki deneyimlerinin yeniden düzenlenmesi yoluyla canlandırmaları söz konusudur (Aykaç, 2005). Eğitimde dramanın kullanımı, sınırları önceden belirlenmiş olan sınıf içi etkinlik programlarının ötesine geçerek, öğrencilerin "mış gibi" davranmanın yeni dünyasıyla tanışmasını amaçlar. Bu bağlamda öğretmen, öğrencilerin gelişimsel dönemlerine uygun roller üstlenebileceği ve serbest katılım gösterebileceği zengin bir ortam hazırlar (Andersen, 2004). Eğitimde drama çoğunlukla sosyal bilimler yahut dil eğitimi alanlarında karşılaşılan sorunların giderilmesinde etkili bir araç olarak kullanılsa da daha spesifik kullanım alanları mevcuttur. Drama uygulamalarına katılan çocuklar, insan doğasını tüm yönleriyle keşfetme deneyimi yaşarlar ve davranışların altında yatan sebepleri bizzat deneyimleyerek çözümleyebilirler (O’Toole, 2002). Örneğin aile bireyleri arasında gerçekleşen bir çatışmayı konu edinen bir metni okuduktan sonra öğrenciler, metindeki karakterlerin motivasyonlarını ve birbirleri ile ilişkilerini canlandırma yoluyla keşfedebilirler (Nagy, Laskey, \& Allison, 1993). Drama tekniği formal ve informal/yaratıcı olmak üzere incelenebilir. Formal drama, genel olarak drama uygulamalarının eğitsel amaçlarına bağlı kalırken, öğrencilerin belirli bir metinden hareketle olayın kendisi ve bağlamı hakkında düşünüp araştırma yapmaları esasına dayanır; olayın kimler arasında ve nasıl cereyan ettiği anlaşılmaya çalışılır (Yaşar \& Gültekin, 2012).

Yaratıcı dramada yaşamın modelini çıkardığımız, bir grup şeklinde çalışarak katılımcıların diğer insanların sorunlarını ve değerlerini öğrendiği, gözlemleyerek diğerlerinin benzer durumlarda neler yaptıklarını değerlendirdikleri ve pek çok sanatsal beceriyi de kullandıkları bir süreçtir. Yaratıcı dramada bireyler verilen konu, tema, olay ve model çerçevesinde rol oyunları oynamakta, doğaçlamalar yapmakta ve bunlar üzerinde değerlendirmeler yaparak var olanı ve olması gerekeni öğrenmektedir (ÖnalanAkfırat, 2006). Yaratıcı drama öğretim sürecinde bireylerin dünyayı anlayabilmesi; çevreleriyle, başkalarıyla ve kendileriyle etkileşim ve iletişime girmeleri için olanaklar sağlanması açısından çok etkili bir güce sahiptir (Üstündağ, 1998). Yaratıcı drama insanların kendilerini gerçekleştirme, kimi fantezilerini işe koşma, mutlu ve hoşnut olmalarına yol açma, kısmen de yaşantılarından estetik bir haz alabilmelerinin yanı sıra eğitim-öğretimde bir yöntem olarak kullanılmasını sağlamak söz konusudur (San, 2006). Temelde drama tekniği doğaçlamaya dayanmakla birlikte bu çalışmada kullanılan formal dramanın başı sonu belli bir senaryonun söz konusu olmasıyla informalden yani yaratıcı dramadan küçük bir farkla ayrılabileceği söylenebilir.

$\mathrm{P}_{\mathrm{b}} \mathrm{DÖ}$ yaklaşımında öğrencilere problemin hissettirilmesi basamağında drama tekniğinin kullanılması, problem durumunun öğrenciler tarafından algılanmasında kolaylık sağlayabilir. $\mathrm{Bu}$ çalışma $\mathrm{P}_{\mathrm{b}} \mathrm{DO}$ süreci ile planlanmış, problemin hissedilmesinde drama tekniği kullanılmış, bu bağlamda da öğrencilere Hayat Bilgisi dersinden seçilen kazanımlara ulaştırabilecek belirli bir senaryo verilip bu senaryo çerçevesinde rollerin canlandırılması istendiği için dramadan yararlanılmıştır. $\mathrm{P}_{\mathrm{b}} \mathrm{DÖ}$ 'nün uygulanmasında gerçek yaşamdan problem durumlarının kullanılmasının önemi göz önünde bulundurularak, bu çalışmada faydalanılan drama senaryosu kapsamında, günlük yaşamda aile içerisinde gerçekleşen bireyler arası iletişimdeki hatalı tutum ve davranışların farkına varılması ve doğru davranışların kazanılması amaçlanmaktadır. Söz konusu kazanımlar ilkokul üçüncü sınıf Hayat Bilgisi Dersi Öğretim Programı'nda şu şekilde açıklanmaktadır (Millî Eğitim Bakanlığı [MEB], 2009): 
- B.3.28: Ailesinde ve yakın çevresinde (akrabaları, komşuları vb.) birbirlerinin haklarına ne ölçüde saygı gösterildiğini gözlemler (Tema: Benim Eşsiz Yuvam);

- B.3.20: Aile içinde görev dağılımının adil olup olmadığını sorgular (Tema: Benim Eşsiz Yuvam);

- B.3.17: Aile içinde ortaya çıkabilecek anlaşmazlıkları çözmek için sorun çözme becerisini kullanır (Tema: Benim Eşsiz Yuvam).

$\mathrm{P}_{\mathrm{b}} \mathrm{DÖ’nün} \mathrm{öğrencilerin} \mathrm{yalnızca} \mathrm{akademik} \mathrm{başarıları} \mathrm{üzerinde} \mathrm{değil,} \mathrm{öğrenme}$ alanına ilişkin tutum ve farkındalıklarının geliştirilmesi üzerinde de etkili olduğu çeşitli araştırmalarla ortaya konmuştur. Baysal, Duman, Arkan ve Hastürk (2012) tarafindan İstanbul ilinde 60 adet beşinci sınıf öğrencisiyle yürütülen çalışmada, Sosyal Bilgiler dersinde $\mathrm{P}_{\mathrm{b}} \mathrm{DÖ}$ uygulanmasının öğrencilerin yazma eğilimlerini ve görsel sunu becerilerini arttırdığ sonucuna ulaşılmıştır. Ilgın ve Arslan (2012) tarafindan ilköğretim ikinci sınıf öğrencileriyle yürütülen çalışmada Türkçe dersinde metinlerle $\mathrm{P}_{\mathrm{b}} \mathrm{DÖ}$ 'nün uygulama aşamalarının çoğunda öğrenci kazanımlarını geliştirdiği bulgulanmıştır. Demirel ve Arslan-Turan (2010) tarafından yürütülen, $\mathrm{P}_{\mathrm{b}} \mathrm{DÖ}$ yaklaşımının ilköğretim altıncı sınıf öğrencilerinin Fen ve Teknoloji dersine yönelik akademik başarıları, tutumları ve biliş ötesi farkındalık düzeyleri üzerine etkilerinin incelendiği araştırmada, $\mathrm{P}_{\mathrm{b}} \mathrm{DÖ}$ yaklaşımının söz konusu alanlar üzerinde anlamlı düzeyde olumlu etkiye sahip olduğu anlaşılmıştır. Benzer şekilde Cantürk-Günhan ve Başer (2008) tarafından yürütülen, ilköğretim yedinci sınıf öğrencilerinin Matematik dersine ilişkin başarıları ve tutumları üzerinde $\mathrm{P}_{\mathrm{b}} \mathrm{DÖ}$ yaklaşımının etkilerinin incelendiği araştırmanın bulguları, bu yaklaşımın yalnızca akademik başarı üzerinde değil, derse yönelik tutum üzerinde de anlamlı düzeyde olumlu etkiye sahip olduğunu ortaya koymuştur.

\section{Araştırmanın Amacı}

$\mathrm{Bu}$ araştırmanın amacı, drama temelli PbDÖ yaklaşımının ilkokul öğrencilerinin empati beceri düzeyleri üzerindeki etkisini incelemektir. Alan yazın incelendiğinde empati becerisinin drama tekniği ile geliştirilmesine yönelik ilköğretim düzeyinde yapılan çalışmalara rastlansa da söz konusu çalışmalar arasında PbDÖ yaklaşımının kullanımına yer verilmediği anlaşılmaktadır. Dolayısıyla bu çalışmanın ilköğretim düzeyinde gerek empati becerisinin geliştirilmesine yönelik bir uygulama süreci önermesi gerekse drama temelli PbDÖ’nün Hayat Bilgisi dersi kapsamında uygulanabilirliğini ortaya koyması bakımından alan yazına önemli bir katkı sağlayacağı düşünülmektedir. Buradan hareketle, bu araştırmaya yön veren problem cümlesi ve problemin çözümüne ulaşmada kullanılan alt-problem cümleleri şu şekilde belirlenmiştir:

Drama temelli $\mathrm{P}_{\mathrm{b}} \mathrm{DÖ}$ yaklaşımı ilkokul öğrencilerinin empati beceri düzeylerini geliştirmede etkili midir?

1. $\mathrm{P}_{\mathrm{b}} \mathrm{DÖ}$ yaklaşımının uygulandığı deney grubu öğrencilerinin empati düzeyleri öntest ve son-test ortalama skorları arasında anlamlı bir farklılık var mıdır?

2. $\mathrm{P}_{\mathrm{b}} \mathrm{DÖ}$ yaklaşımının uygulanmadığı kontrol grubu öğrencilerinin empati düzeyleri ön-test ve son-test ortalama skorları arasında anlamlı bir farklılık var midir?

3. $\mathrm{P}_{\mathrm{b}} \mathrm{DÖ}$ yaklaşımının uygulandığı deney grubu öğrencilerinin empati düzeyleri son-test ortalama skorları ile $\mathrm{P}_{\mathrm{b}} \mathrm{DÖ}$ yaklaşımının uygulanmadı̆̆ı kontrol grubu 
öğrencilerinin empati düzeyleri son-test ortalama skorları arasında anlamlı bir farklılık var midır?

\section{Yöntem}

$\mathrm{Bu}$ araştırmada ön test-son test kontrol gruplu yarı deneysel model kullanılmıştır. Yarı deneysel model, gerçek deneysel modelin uygulanmasının belirli nedenlerle güçlükler taşıdığı durumlarda özellikle toplumbilimlerinde sıkça başvurulan bir modeldir ve uygulama geçerliliği yüksektir. Modelde deney ve kontrol grupları gelişigüzel oluşturulurken, hangisinin deney hangisinin kontrol grubu olacağı yansız bir seçimle kararlaştırılır (Karasar, 2011). Çalışmada eşdeğer kabul edilen aynı hizmet bölgesi ve aynı hizmet alanından iki farklı grup birisi deney diğeri kontrol grubu olarak rastgele seçildiği için bu desen kullanılmıştır. Bu doğrultuda araştırmanın deseni aşağıdaki gibidir:

Tablo 1

Araştırmanın Deneysel Deseni

\begin{tabular}{llll}
\hline Gruplar & Ön-test & Deneysel işlem & Son-test \\
\hline Deney grubu & ÇiEÖ & Drama Temelli $\mathrm{P}_{\mathrm{b}} \mathrm{DÖ}$ & ÇiEÖ \\
Kontrol grubu & ÇiEÖ & - & ÇंEÖ \\
\hline
\end{tabular}

Drama temelli $\mathrm{P}_{\mathrm{b}} \mathrm{DÖ}$ yaklaşımının ilkokul öğrencilerinin empati beceri düzeylerine etkisinin incelenmesi için deney grubundaki öğrencilerle drama tekniği ile problemin hissettirildiği $\mathrm{P}_{\mathrm{b}} \mathrm{DÖ}$ uygulaması yapılmış, kontrol grubundaki öğrencilerle ise Hayat Bilgisi ders kitabında yer alan konular herhangi bir deneysel yöntem kullanılmadan işlenmiştir. Kontrol grubunda ders kazanımları doğrultusunda anlatım ve soru-cevap teknikleri kullanılmıştır.

\section{Çalışma Grubu}

$\mathrm{Bu}$ araştırmanın çalışma grubunu 2017-2018 eğitim-öğretim yılında İstanbul ili Fatih ilçesinde yer alan bir ilkokuldaki (2. Hizmet Bölgesi, 5. Hizmet Alanı) 24 üçüncü sınıf öğrencisi ile İstanbul ili Güngören ilçesinde yer alan bir ilkokuldaki (2. Hizmet Bölgesi, 5. Hizmet Alanı) 24 üçüncü sınıf öğrencisi oluşturmaktadır. Öğretmen ihtiyac1, coğrafi durum, ekonomik ve sosyal yönden gelişmişlik düzeyi, ulaşım şartları ile hizmet gereklerinin karşılanması yönünden örneklem seçilen okullar 2. Hizmet Bölgesinde yani ortanın üzerinde sosyo-ekonomik düzeyde yer almakta, bu okullarda görev yapan aynı zamanda araştırmacı öğretmenler ise iyi düzeyde puana sahip bulunmaktadır.

Çalışma grubu araştırmacılardan ikisi için kolay ulaşımın sağlanabildiği iki devlet okulundan seçildiğinden kolay ulaşılabilir örnekleme yöntemi kullanılmıştır. Bu tür örneklemede araştırmacılar çalışma grubu için uygun olan bireyleri araştırmanın amaç ve kapsamına bağlı olarak seçerler; belirlenen çalışma grubunun evreni genel hatlarıyla yansıtacağı varsayımına dayanılır. Araştırmacıların önceki bilgi, deneyim ve becerileri bu örnekleme yönteminin kullanılmasında önem taşır (Balc1, 2010). 


\section{Veri Toplama Araci}

$\mathrm{Bu}$ araştırma kapsamında verilerin toplanması için “Çocuklar İçin Empati Ölçeği (ÇİEÖ)" kullanılmıştır. ÇİEÖ ilk olarak Mehrabian ve Epstein (1972) tarafindan "Yetişkinler İçin Empati Ölçeği” adıyla geliştirilmiş olup, Bryant (1982) tarafindan "Çocuklar ve Ergenler için Empati Ölçeği” şeklinde adapte edilmiştir. Ölçeğin Türkçeye uyarlanması ise Yüksel (2004) tarafından gerçekleştirilmiştir. Türkçe versiyonunun tekrarlı test yöntemi ile hesaplanan güvenilirlik katsayısı $r=.069$, iç tutarlılık (Cronbach Alpha) katsayısı ise .70'tir. Türkçeye uyarlama sürecinin ardından yapılan geçerlilik çalışmasında madde yükü .245 ve üstünde olanlar ölçeğe dahil edilmişstir. Orijinali 22 maddeden oluşan ölçeğin iki maddesi kapsam dışı bırakılmış ve madde sayısı 20 olarak belirlenmiştir. Ölçekten alınabilecek en düşük skor 0, en yüksek skor 20'dir.

\section{Verilerin Analizi}

Araştırmanın veri analizinde istatistik yazılımı kullanılmıştır. Araştırma sorularına bağlı olarak, öncelikle deney ve kontrol grubu skorlarının normal dağılım gösterip göstermediği incelenmiştir. Örneklem skorlarının normal dağılım gösterdiği durumlarda parametrik, normal dağılım göstermediği durumlarda ise parametrik olmayan testler kullanılır (Büyüköztürk, Çokluk, \& Köklü, 2011). Grup büyüklügüünün 50'den küçük olması durumunda Shapiro-Wilk, büyük olması durumunda ise Kolmogorov-Smirnov testi kullanılır (Büyüköztürk, 2012). Bu araştırmada deney ve kontrol grupları 24'er kişiden oluştuğu için grupların skor dağılımlarının normallik testi için Shapiro-Wilk testinin kullanılması uygun görülmüştür.

Tablo 2'den anlaşılabileceği gibi her iki gruba ait skorlara ilişkin Shapiro-Wilk testindeki $\mathrm{p}$ değerleri .05 'ten büyük olduğu için $\left(Z_{\text {kontrol }}=.935\right.$; $p>.05$ ve $Z_{\text {deney }}=.939$; p>.05) skor dağılımlarının normal dağılım gösterdiği söylenebilmektedir. Buradan hareketle ilerleyen aşamalarda verilerin analizi için parametrik testlerin kullanılabileceği anlaşılmaktadır.

Tablo 1

Deney ve Kontrol Grubu ÇİEÖ Ön-Test Skorlarının Shapiro-Wilk Normal Dă̆llım Analizi

\begin{tabular}{llccccc}
\hline & $N$ & $\bar{X}$ & $Z$ & $s d$ & $p$ \\
\hline \multirow{2}{*}{ Ön-test Skoru } & Kontrol grubu & 24 & 14.630 & .935 & 24 & .127 \\
& Deney grubu & 24 & 13.500 & .939 & 24 & .155 \\
\hline
\end{tabular}

\section{Deneysel İşlem Öncesi Grupların ÇíEÖ Skorlarının Karşılaştırılması}

Deneysel işlem öncesinde grupların Çi̇EÖ skorları arasında istatistiksel olarak anlamlı düzeyde fark olup olmadığını test etmek amacıyla parametrik testlerden olan bağımsız gruplar t-testi kullanılmış ve sonuçlar Tablo 3'te gösterilmiştir.

Tablo 3'ten anlaşılabileceği gibi kontrol grubunun ön-test ÇİEÖ skorlarının ortalamas1 14.630; deney grubunun ise 13.500 olmuştur. Grupların ön-test ortalama skorları arasında anlamlı düzeyde farklılık olup olmadığının tespiti için yapılan bağımsız gruplar t-testi sonucuna göre, grupların ortalama skorları arasında anlamlı bir 
fark bulunmamaktadır $\left(\mathrm{t}_{(46)}=1.722 ; \mathrm{p}>.05\right)$. Dolayısıyla her iki grubun ÇİEÖ ön-test skorları açısından denk olduğu ve deneysel uygulamaya geçilebileceği anlaşılmaktadır.

Tablo 2

Deney ve Kontrol Grubu ÇİEÖ Ön-Test Skorlarına İlişkin Bă̆ımsız Gruplar T-Testi Analizi

\begin{tabular}{|c|c|c|c|c|c|c|}
\hline Grup & $N$ & $\bar{X}$ & ss & $s d$ & $t$ & $p$ \\
\hline Kontrol grubu & 24 & 14.630 & 2.242 & \multirow{2}{*}{46} & \multirow{2}{*}{1.722} & \multirow{2}{*}{.092} \\
\hline Deney grubu & 24 & 13.500 & 2.284 & & & \\
\hline
\end{tabular}

\section{Deneysel İşlem Uygulama Aşamaları}

Deneysel uygulama öncesinde öğrencilere $\mathrm{P}_{\mathrm{b}} \mathrm{DÖ}$ yaklaşımıyla öğrenme sürecine ilişkin temel aşamaların tanıtıldığı bir sunum yapılmıştır. Bu sunum, yaş düzeyi göz önünde bulundurularak, uygulama aşamalarının nasıl izleneceği konusunda bilgi vermeyi amaçlamaktadır. Böylelikle öğrencilerin problem durumunun farkına varma aşamasından başlayarak, problemi tanımlama, çözüm önerileri geliştirme ve olası çözümlerin işlerliğini denetleyip kesin çözüme ulaşana kadarki süreci çalışma gruplarında işletebilmeleri beklenmiştir. Toplam dokuz ders saatinde üç haftada gerçekleştirilen $\mathrm{P}_{\mathrm{b}} \mathrm{DÖ}$ yaklaşımının uygulama aşamalarına bağlı kalınmak suretiyle (Gijselaers, 1995; Kaptan \& Korkmaz, 2001; Schultz \& Christensen, 2004; Schmidt, 1983), problemin hissedilmesi için drama tekniğinden yararlanılan süreç şu şekilde gerçekleştirilmiştir:

Problemin farkına varılması. Aile içerisinde haklara saygı, görev dağılımı açısından iletişim çatışmalarını örneklemek ve böylece karakterlerin düşünce ve duygularını hissettirerek çözülecek bir durum yaratmak için araştırmacılar tarafından oluşturulan senaryoda aile içinde gerçekleşen günlük bir yaşantı sergilenir. Söz konusu senaryo eğitimde drama uygulamaları konusunda eğitim almış bir sınıf öğretmeni, eğitimde yaratıcı drama ve psikodramanın kullanımı alanında sertifikalı bir sınıf öğretmeni ve çağdaş öğretim stratejileri alanında uzman bir akademisyen tarafından hazırlanmıştır. Senaryonun gelişimsel döneme uygunluğunun ve dilsel yeterliliklerinin teyit edilebilmesi için temel eğitimde drama uygulamaları alanında uzman bir akademisyenin görüşlerine başvurulmuştur. Senaryo üzerinde anlaş1lırlık ve müfredat kapsamına uygunluk bağlamında gerekli düzeltmeler sağlandıktan sonra bu araştırmanın kapsamındaki okullardan birinde, deney ve kontrol gruplarının dışında kalan, 22 kişiden oluşan bir 4. sınıf öğrenci grubuyla pilot uygulama yürütülmüştür. Pilot uygulama süresince öğrencilerin de senaryonun anlaş1labilirliğine ve uygulanabilirliğine ilişkin görüşlerine başvurulmuş ve uygulama sürecinde karşılaşılan güçlük ve hatalar dikkate alınarak metin tekrar gözden geçirilmiştir. Hazırlanan senaryoda aile bireylerinin birbirleriyle kurdukları iletişimde yaşanan rahatsız edici durumlar bulunmaktadır. Bir öğrenci grubunca sergilenen drama uygulamasının izlenmesi ve öğrencilerin senaryoda yer alan problem durumunun farkına varmaları beklenmektedir. $\mathrm{Bu}$ aşamada öğrencilerin senaryoda işlenen problem durumunu sezmeleri ve çalışma gruplarında tartışmalar yürüterek bir kavram haritası oluşturmaları ve ulaştıkları yargıları paylaşmaları amaçlanmaktadır. 


\section{Drama Senaryosu}

\section{Afiyet Olsun!}

Çocuk okuldan eve gelir. Çantasını ve kıyafetlerini çıkartır ve salonda bir koltuğun üzerine firlatıp bilgisayarın başında oyun oynamaya başlar. Anne evin içinde koşuşturmaktadır. Bir taraftan yemekle ilgilenmekte, bir taraftan da çocuğun eşyalarını toplamaya çalışmaktadır. Sürekli söylenir, çocuğun kendi eşyalarını toplamasını ve kendisine yardımcı olmasını ister. Çocuk hiç oralı olmaz.

Bir süre sonra çocuğun ağabeyi/ablası okuldan gelir. $O$ da aynı şekilde çantasını ve kıyafetlerini salona fırlatır. Küçük çocuğu bilgisayarın başından zorla kaldırır ve bilgisayarda araştırma yapması gerektiğini söyler. Küçük çocuk annesinden yardım ister. Annesi çok işi olduğunu ve onunla ilgilenemeyeceğini ifade eder. Büyük çocuk annesinden araştırması için yardım ister; anne ona da aynı şekilde cevap verir: Sofrayı hazırlaması gerektiğini söyler ve çocuklardan yardım ister. Büyük çocuk bilgisayarın başından kalkmaz, küçük çocuk da koltukta üzülmüş ve sinirlenmiş bir halde oturur.

Bir süre sonra baba gelir, sevinçle çocuklarla karşılaşmayı bekler. Çocukların ikisi de babayla ilgilenmez ve babanın suratı asılır. Anne babaya hoş geldin der, onu karşılar, gününün nasıl geçtiğini sorar. Baba bu soruyu ve hoş karşılamayı geçiştirir, sofranın hazır olup olmadığını sorar. Herkes sofraya oturur. Hepsinin suratı asıktır ve kimse yemek istemez. Anne herkese seslenir: "Afiyet olsun!"

Problemin doğru biçimde açıklanması. İzleyici ve oynayıcı öğrenci gruplarının senaryoda gerçekleşen problem durumuna ilişkin açıklamalar getirmeleri ve senaryoda aile bireylerinin birbirleriyle kurdukları iletişim biçimi nedeniyle karşılaştıkları güçlüklerin ifade edilmesi beklenmektedir. $\mathrm{Bu}$ aşamada öğrencilerin karakterler arasındaki iletişimde doğru ve yanlış olan ifade ve davranışları ayırt etmeleri, bu tespitlerini gruplara dağıtılan çalışma kâğıdına işlemeleri amaçlanmaktadır.

\section{Şekil 1. Problemin Doğru Biçimde Açıklanmasına Yönelik Doğru/Yanlış} Davranışlar Çalışma Kâğıdı

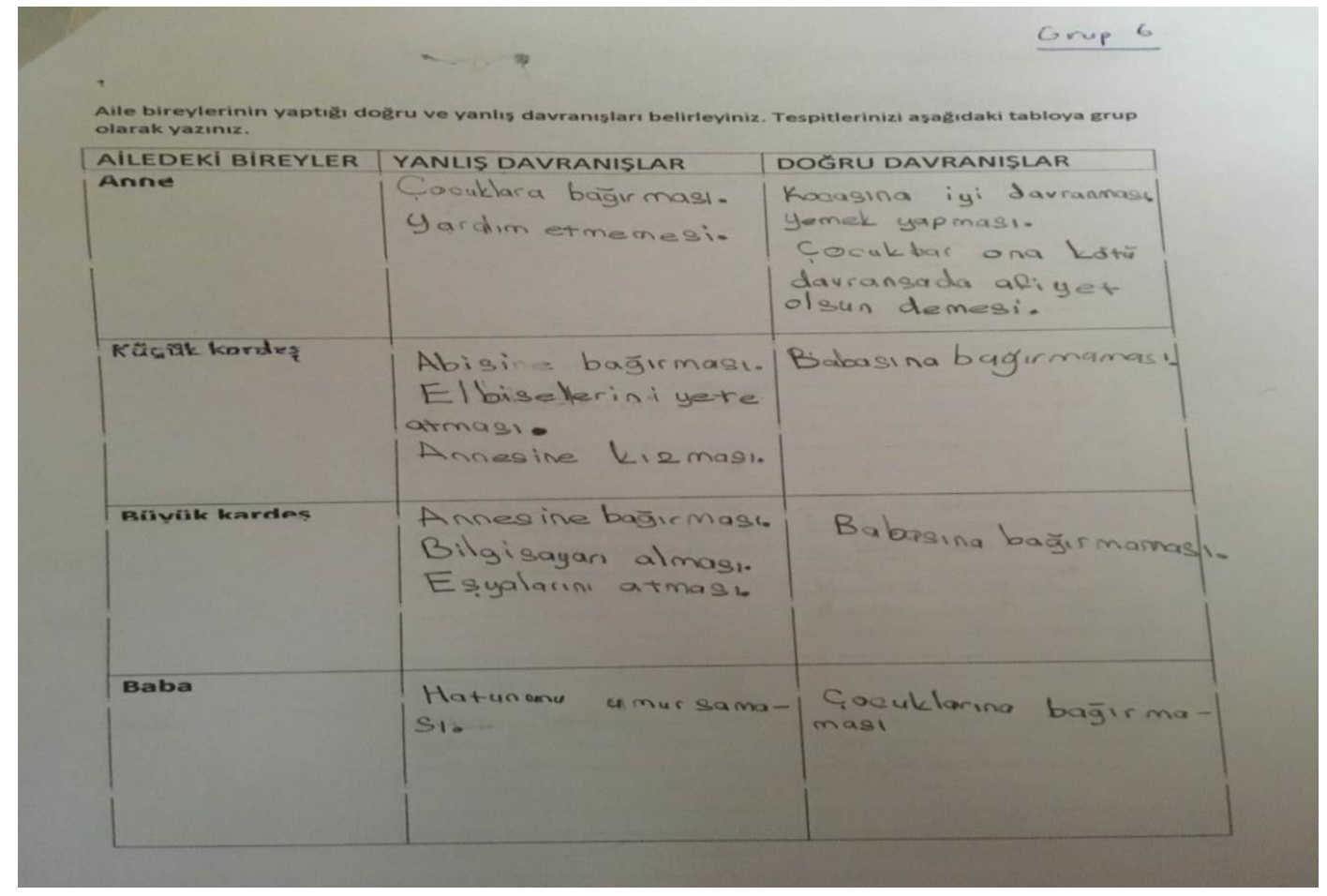


Problemi çözmek için gereken bilgilerin belirlenmesi. İzlenen senaryoda fark edilip açıklanan problem durumunun aşılmasına yönelik çözüm için öğrencilerin hangi bilgilere sahip olmaları gerektiğine karar vermeleri beklenmektedir.

Bilgi toplamak için kullanılabilecek kaynakların belirlenmesi. Senaryoda ortaya konan problemli durumun çözümü için hâlihazırdaki bilgi ve deneyimlerinin dışında başka hangi bilgilere sahip olunması gerektiğine karar verilmesi beklenmektedir. Öğrencilerin kendi deneyimleri dışında, yaşanan durumun diğer aile bireylerinin bakış açısından nasıl gerçekleştiğini anlayabilmek için röportajlar/görüşmeler gerçekleştirmeleri ve diğer bilgi kaynaklarına yönelmeleri istenmektedir. $\mathrm{Bu}$ aşamada çalışma grubundaki her öğrencinin, öncelikle bireysel araştırmalar yapmaları ve elde ettikleri verileri gruplarında paylaşmaları beklenmektedir. Senaryo kapsamında, söz konusu problem durumunun öznesi olan aile bireylerinin görüşlerinin alınabilmesi için, sınıf ortamına anne, baba, abla, ağabey gibi figürleri temsilen yetişkinlerin davet edilmesi sağlanır. Bu süreçte çalışma gruplarının aile bireyleri ile görüşmeler yapması ve problemin çözümüne yönelik notlar alarak paylaşmaları amaçlanmaktadır.

Olası çözümlerin oluşturulması. Öğrencilerin kendi deneyim ve bilgileri yanında, diğer aile bireylerinin bakış açılarını keşfetmeye yönelik yaptıkları araştırmalardan elde ettikleri bilgileri çalışma gruplarında paylaşmaları ve çalışma gruplarında toplanan bilgiler 1şığında, senaryoda yer alan problem durumunun çözümüne yönelik başlangıç çözümlerinin kurgulanması beklenmektedir. Bu aşamada çalışma gruplarının önceki aşamada elde edip paylaştıkları veriler üzerinden problem durumunun çözümüne yönelik öneriler geliştirmeleri amaçlanmaktadır.

Çözümlerin İrdelenmesi. $\mathrm{Bu}$ aşamada çalışma gruplarında kurgulanan çözümlerin sınanması için öğrenci gruplarının söz konusu senaryoyu canlandırmaları ve tüm çalışma gruplarının problem durumunun çözümü için geliştirilen drama uygulamalarını tekrar izleyerek kendi çözüm kurgularını gözden geçirip iyileştirmeleri amaçlanmaktadır.

Çözümün ortaya konması ve öz-değerlendirme. Senaryoda ortaya konan problem durumunun çözümüne yönelik kurgulanıp düzenlenen dramanın tekrar sergilenmesi ve çalışma gruplarının kendi çözüm kurgularının, problem durumunun çözümü için etkililiğinin tartışılması beklenmektedir. Bu aşamada ortaya konan çözümle birlikte, öğrencilerin bireysel olarak kendi değerlendirmelerini yapmaları amaçlanmaktadır (Şekil 2). 
Şekil 2. Ortaya Konan Çözümün Ardından Uygulama Bitiminde Kullanılan ÖzDeğerlendirme Formu

\section{ETKINLIK ÖZ-DEǦERLENDIRME FORMU}

Adım, soyadım: .E.lis....Serna......Dog.i.

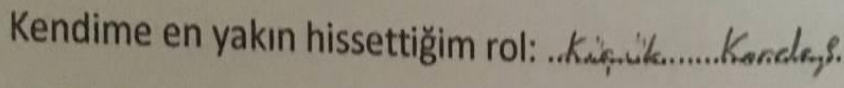

Neden?

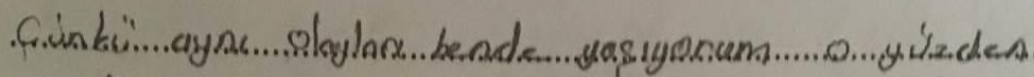

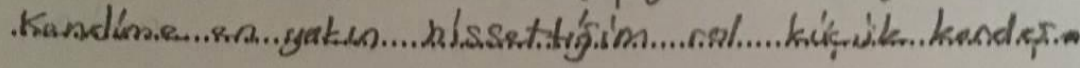

Aşağıdaki tabloyu tüm rolleri düşünerek işaretleyiniz.

\begin{tabular}{|l|c|c|c|}
\hline Ölçütler & Yapabildim & $\begin{array}{c}\text { Biraz } \\
\text { yapabildim }\end{array}$ & Yapamadım \\
\hline $\begin{array}{l}\text { Oynadığım roldeki kişilerin ne } \\
\text { hissettiğini anlayabildim. }\end{array}$ & $\checkmark$ & & \\
\hline $\begin{array}{l}\text { Oynadığım roldeki kişilerin yanlış } \\
\text { davranışlarını farkettim. }\end{array}$ & $\checkmark$ & & \\
\hline $\begin{array}{l}\text { Oynadığım roldeki kişilerin nasıı } \\
\text { doğru davranabileceğini anladım. }\end{array}$ & $\checkmark$ & & \\
\hline
\end{tabular}

Bu etkinlikten neler öğrendim?

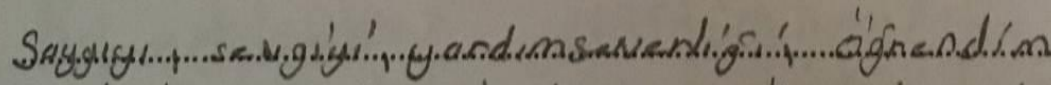

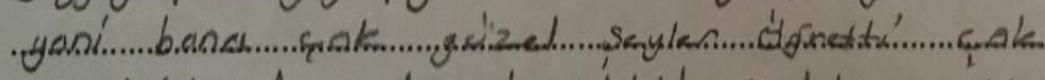

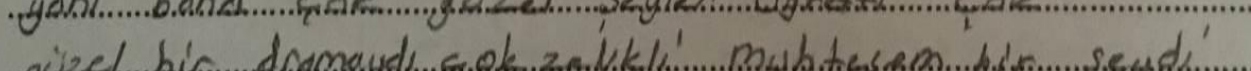

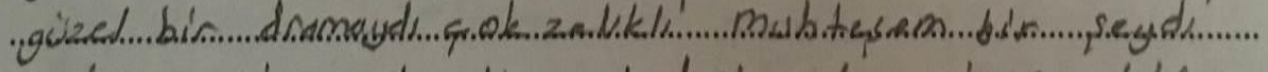

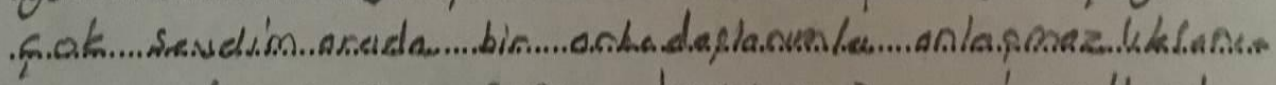

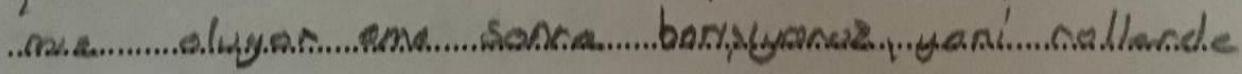

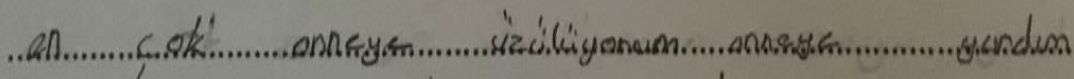

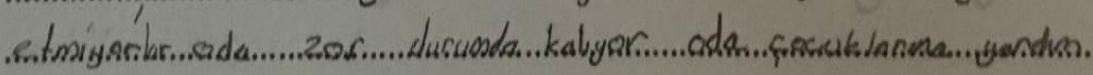
...rdemizar.r.

Deney grubuna yönelik problemin hissedilmesi için drama tekniğinden yararlanılarak gerçekleştirilen $\mathrm{P}_{\mathrm{b}} \mathrm{DÖ}$ süreci takvimi Tablo 4'te gösterilmiştir: 
Tablo 4

Drama Temelli $P_{b} D O ̈$ Yaklaşımı Uygulama Aşamaları Takvimi

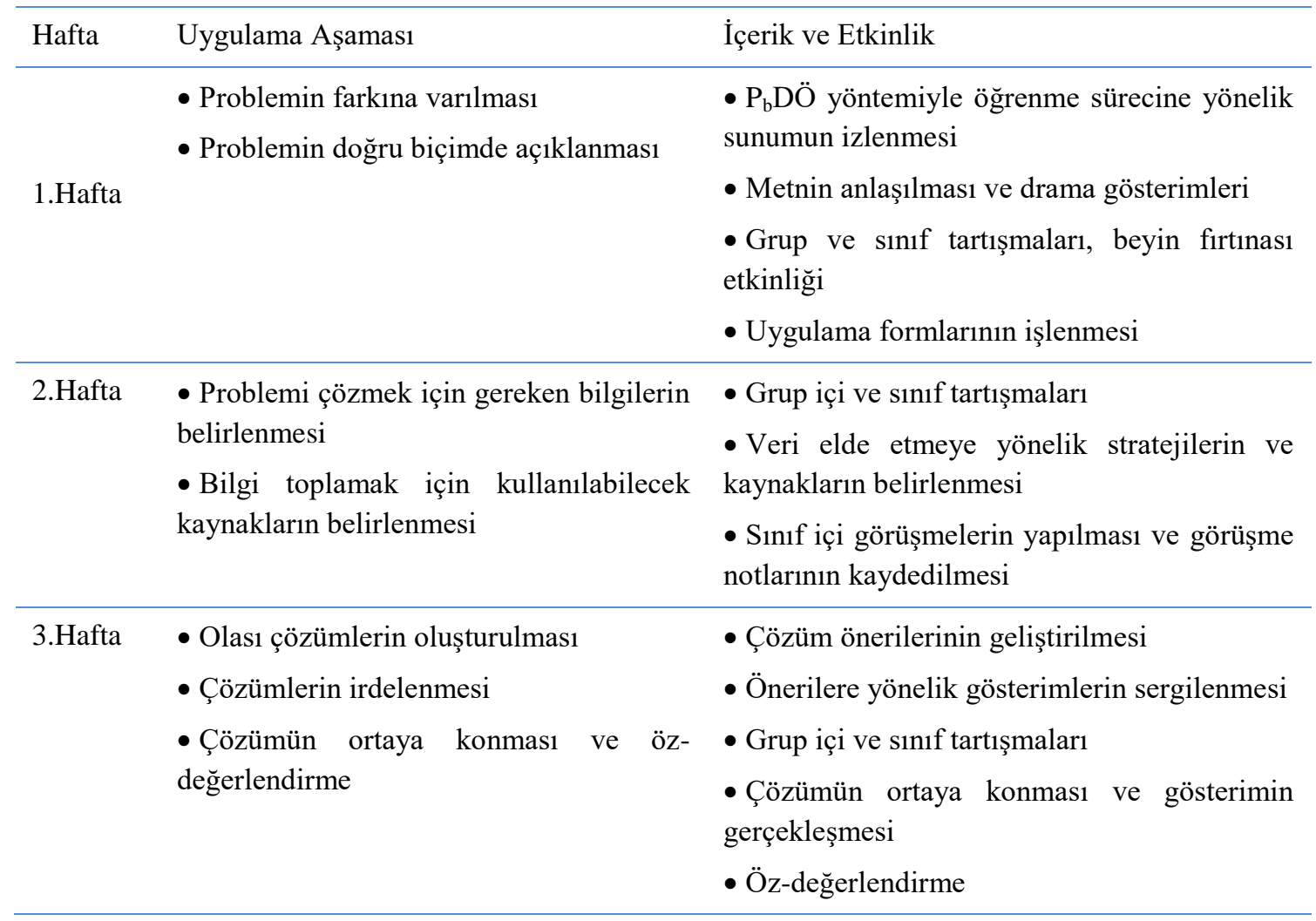

\section{Bulgular}

Araştırmanın birinci ve ikinci alt-problemleri uyarınca uygulama aşamaları sonrasında kontrol ve deney gruplarının kendi içlerinde ÇİEÖ ön-test ve son-test skorları açısından anlamlı bir farklılık gösterip göstermediklerinin anlaşılabilmesi için bağımlı gruplar t-testi kullanılmış ve sonuçlar Tablo 5'te gösterilmiştir.

Tablo 5'ten anlaşılabileceği gibi kontrol grubunun ÇİEÖ ön-test ve son-test skorları arasında anlamlı bir farklılaşma görülmezken $\left(\mathrm{t}_{(23)}=2,001, \mathrm{p}>, 05\right)$, deney grubunda ise anlamlı bir farklılaşmanın olduğu görülmektedir $\left(\mathrm{t}_{(23)}=-5,786, \mathrm{p}<, 05\right)$. Bir başka deyişle, herhangi bir deneysel işlemin uygulanmadı̆̆ kontrol grubunun ÇİEÖ skorları kayda değer bir değişme göstermezken, drama temelli $\mathrm{P}_{\mathrm{b}} \mathrm{DÖ}$ uygulamasının yapıldığı deney grubunun ÇİEÖ skorlarında anlamlı düzeyde bir artış meydana gelmiştir. Dolayısıyla drama temelli $\mathrm{P}_{\mathrm{b}} \mathrm{DÖ}$ yaklaşımının deney grubundaki öğrencilerin empati düzeylerinin geliştirilmesi bakımından etkili olduğu anlaşılmaktadır.

Tablo 3

Grupların ÇİË̈ Ön-Test ve Son-Test Skorlarına İlişkin Bağımlı Gruplar T-Testi Analizi

\begin{tabular}{lccccccc}
\hline Grup & & $N$ & $\bar{X}$ & $s s$ & $s d$ & $t$ & $p$ \\
\hline \multirow{2}{*}{ Kontrol grubu } & Ön-test & & 14.630 & 2.242 & 23 & 2.001 & .057 \\
& Son-test & & 13.710 & 2.726 & & & \\
\hline \multirow{2}{*}{ Deney grubu } & Ön-test & \multirow{2}{*}{24} & 13.500 & 2.284 & \multirow{2}{*}{23} & -5.786 & .000 \\
& Son-test & & 15.250 & 2.364 & & & \\
\hline
\end{tabular}


Araştırmanın 3. alt-problemi uyarınca kontrol ve deney gruplarının ÇİEÖ sontest skorları açısından anlamlı bir farklılık gösterip göstermediklerinin anlaşılabilmesi için bağımsız gruplar t-testi kullanılmış ve sonuçlar Tablo 6' da gösterilmiştir.

Tablo 6'dan anlaşılabileceği gibi kontrol grubunun son-test ÇİEÖ skorlarının ortalamas1 13.710; deney grubunun ise 15.250 olmuştur. Grupların son-test ortalama skorları arasında anlamlı düzeyde farklılık olup olmadığının tespiti için yapılan bağımsız gruplar t-testi sonucuna göre, grupların ortalama skorları arasında deney grubu lehine anlamlı bir farklılı bulunmaktadır $\left(\mathrm{t}_{(46)}=-2.093 ; \mathrm{p}<.05\right)$. Dolayısıyla kontrol ve deney gruplarının ön-test skorları açısından birbirine denk oldukları düşünüldüğünde, drama temelli $\mathrm{P}_{\mathrm{b}} \mathrm{DÖ}$ uygulamasının öğrencilerin empati düzeylerini geliştirmede etkili olduğu anlaşılmaktadır. Grupların ortalama skorları arasındaki farklılaşma manidar bulunmuş olsa da bu farklılaşmanın deney grubuna uygulanan $\mathrm{P}_{\mathrm{b}} \mathrm{DÖ}$ yaklaşımıyla yürütülen programdan (bağımsız değişken) ne düzeyde etkilendiğinin bilinmesi de önemlidir. Söz konusu etki büyüklüğü $\left(\eta^{2}\right)$, test skorlarındaki varyansın ne kadarının bağımsız değişkene bağlı olduğuna ilişkin yorumlama imkanı sunar ve .01 küçük, .06 orta ve .14 büyük etki büyüklüğü olarak yorumlanır (Büyüköztürk, Çokluk, \& Köklü, 2011). Deney ve kontrol gruplarının ÇİEÖ son-test skorları için hesaplanan etki büyüklüğü de $\left(\eta^{2}=.087\right)$ ortalamalar arasındaki farka ilişkin orta düzeyde bir etki büyüklüğünü göstermektedir.

Tablo 4

Deney ve Kontrol Grubu ÇİEÖ Son-Test Skorlarına İlişkin Bağımsız Gruplar T-Testi Analizi

\begin{tabular}{lccccccc}
\hline Grup & $N$ & $\bar{X}$ & $s s$ & $s d$ & $t$ & $p$ & $\eta 2$ \\
\hline Kontrol grubu & 24 & 13.710 & 2.726 & 46 & -2.093 & .042 & .087 \\
Deney grubu & 24 & 15.250 & 2.364 & & & & \\
\hline
\end{tabular}

\section{Tartışma ve Sonuç}

Araştırmadan elde edilen bulgular ışı̆̆ında, drama temelli $\mathrm{P}_{\mathrm{b}} \mathrm{DÖ}$ yaklaşımının, ilkokul öğrencilerinin empati düzeyini geliştirmede soru-cevap, anlatım gibi öğrencilerin aktif olarak katılım göstermedikleri öğrenme süreçlerine kıyasla daha etkili sonuç verdiği anlaşılmaktadır. $\mathrm{Bu}$ durum, alan yazında gerek $\mathrm{P}_{\mathrm{b}} \mathrm{DÖ}$ yaklaşımı gerekse drama ve rol oynama tekniklerinin etkililiğine yönelik yapılan araştırmalarla desteklenmektedir.

Yüksel (2004) tarafından hazırlanan empati eğitim programının ilkokul dördüncü sınıf öğrencilerinin empati düzeylerini geliştirdiği; Şahin (2012) tarafından hazırlanan akran zorbalığını önleme programının, ilköğretim altıncı sınıf öğrencilerinin akran zorbalığ̣ davranışlarını önemli ölçüde gerilettiği ve öğrencilerin empati becerileri üzerinde geliştirici etkiye sahip olduğu ortaya konmuştur. Kasapoğlu ve Güneysu (2017) tarafından yürütülen çalışmada ise duygusal zekâ becerilerinin yaratıcı drama ile geliştirilmesinin öğrenci memnuniyeti açısından olumlu sonuçlarının olduğu bulgulanmıştır. Çalışma sonunda öğrenciler sinirlerini kontrol etme, olumsuz duygularını olumluya çevirebilme, hayal güçlerini geliştirme ve empati kurma gibi becerilerinin arttığını belirtmişlerdir. Keski ve Aykaç (2014) tarafından, aile içi iletişim 
engellerinin yaratıcı drama ve empati uygulamalarıyla aşılması amacıyla ilköğretim velileri ile yürütülen çalışmada söz konusu uygulamaların öğrenci velilerinin aile içi iletişimde karşılaştıkları sorunların çözümünde olumlu yönde katkı sağladığı ortaya konmuştur.

Kalliopuska (1992) tarafından geliştirilen ve Finlandiya'da 665 öğrenciyle (5, 8 ve 10. sınıflar) yürütülen empati geliştirme programının da öğrencilerin empati düzeylerini önemli ölçüde yükselttiği anlaşılmaktadır. Sözü edilen programların hepsinde de ağırlıklı olarak drama ve rol oynama etkinliklerinden faydalanıldı̆̆ görülmektedir. McNaughton (2007) tarafından yürütülen, ilkokul öğrencilerinin aktif vatandaşlık bilinci edinmeleri yönünde drama tekniğinin etkililiğinin araştırıldı̆̆ çalışma, drama uygulamalarının söz konusu edinimlerle ilgili gerek tutum gerekse beceriler kapsamında olumlu etkiye sahip olduğunu ortaya koymuştur. Yine Kosti, Kondoiyanni ve Tsiaras (2015) tarafından altıncı sınıflarla yürütülen çalışmada da, tarihî olayların farklı bakış açılarıyla değerlendirilebilmesi için empati becerisinin drama tekniği ile geliştirilmesinde olumlu sonuçlara ulaşıldığı bulgulanmıştır.

Yaratıcı drama uygulamalarının 3. ve 4. sınıf öğrencilerinin benlik algıları, sosyal becerileri ve problemli davranışları üzerindeki olası etkilerinin incelendiği araştırmada Freeman, Sullivan ve Fulton (2003), söz konusu uygulamaların 237 öğrenciden oluşan katılımcı grubun benlik algıları, sosyal becerileri ve problemli davranışları üzerinde istatistiksel olarak anlamlı etkisinin bulunmadığını ortaya koymuşlardır. Buna rağmen araştırmacılar, uygulayıcının tutum ve tercihleri ile uygulamanın süresi dikkate alındığında revize edilmiş bir çalışmanın istatistiksel açıdan anlamlı bir farklılaşma yaratabileceğini ifade etmişlerdir. Curtis vd. (2013) tarafından yetişkin, genç ve çocukların çevre duyarlılığının geliştirilmesi yönünde dramanın kullanıldığı çalışmada araştırmacılar, her üç grubun çevre duyarlılıklarının geliştiğini ve buna paralel olarak davranışlarının sonuçlarıyla yüzleşme bilinçlerinin zenginleştiğini ortaya koymuşlardır. Günümüz çocuk ve gençlerinin dijitalleşen dünyanın olanaklarının çarpık kullanmı nedeniyle siber-zorbalık tuzağına yakalanmakta olduklarını ifade eden Hicks, Le Clair ve Berry (2016), drama uygulamalarının kullanıldığ 1 bir empati programının okul müfredatlarına empoze edilmesiyle birlikte kendini bedensel ve sözel olarak ifade ederek bir başkasının yerine koyma deneyiminin siber-zorbalığın ciddi bir tehdit olarak algılanmasını kolaylaştıracağını ve sözü edilen davranışların önüne geçilebileceğini belirtmektedirler. Benzer şekilde Catterall (2007) tarafından ortaokul öğrencilerinin akran çatışmalarını çözme becerilerinin drama uygulamalarıyla geliştirilmesine yönelik yürütülen 24 haftalık çalışma sonucunda, öğrencilerin çatışma çözme becerilerinde, sosyal iletişim becerilerinde ve drama uygulamalarına yönelik tutumlarında kaydadeğer gelişmeler gerçekleştiği ortaya konmuştur.

$\mathrm{P}_{\mathrm{b}} \mathrm{DÖ}$ yaklaşımının ise alan yazında ağırlıklı olarak fen bilimleri, tıp ve matematik alanlarında, özellikle akademik başarı üzerindeki etkileri açısından incelendiği anlaşılmaktadır. Buna karşın, yöntemle ilgili yapılan araştırmalarda, öğrencilerin $\mathrm{P}_{\mathrm{b}} \mathrm{DÖ}$ yaklaşımına yönelik tutumlarının da göz önünde bulundurulduğu görülmektedir. Söz konusu araştırmalar genel olarak öğrencilerin $\mathrm{P}_{\mathrm{b}} \mathrm{DÖ}$ yaklaşımının uygulanmasına yönelik pozitif bir tutuma sahip olduklarını ortaya koyması açısından eldeki çalışmanın bulgularıyla örtüşmektedir.

Akınoğlu ve Tandoğan (2007) tarafından 2004-2005 eğitim-öğretim yılında, İstanbul ilinde 50 adet yedinci sınıf öğrencisiyle yürütülen çalışmada, öğrencilerin Fen 
Bilimlerine yönelik tutumlarının olumlu yönde etkilendiği ortaya konmuştur. Araştırmaya katılan öğrenciler problem çözme becerilerinin geliştiğini, dersten daha çok keyif aldıklarını ve grup içinde çalışmanın kendilerini daha çok motive ettiğini ifade etmişlerdir. Benzer şekilde Çiftçi, Meydan ve Ektem (2007) tarafından 2004-2005 eğitim-öğretim yılında, Konya ilinde 40 adet altıncı sınıf öğrencisiyle yürütülen çalışma sonucunda öğrencilerin Sosyal Bilgiler dersine yönelik tutumlarının pozitif yönde anlamlı düzeyde arttığı ortaya konmuştur. Ülger (2012) tarafından Görsel Sanatlar dersi biçimlendirme ünitesi kapsamında Ankara ilinde 72 adet yedinci sınıf öğrencisiyle yürütülen çalışmada da öğrencilerin problem çözme becerilerini geliştirdikleri ve dersten daha çok keyif aldıkları ifade edilmiştir.

Ülger ve İmer'in (2013) ilköğretim yedinci sınıf öğrencileriyle yürüttükleri $\mathrm{P}_{\mathrm{b}} \mathrm{DÖ}$ 'ye dayalı görsel sanatlar eğitimi uygulamalarına yönelik çalışmaları, görsel sanatlar eğitiminde $\mathrm{P}_{\mathrm{b}} \mathrm{DÖ}$ yaklaşımının öğrencilerin yaratıcı düşünme becerileri üzerinde anlamlı bir etki yarattığını ortaya koymuştur. Benzer şekilde $\mathrm{P}_{\mathrm{b}} \mathrm{DÖ’nün}$ yaratıcı düşünmeyi geliştirici etkisini bulgulayan (Yaman \& Yalçın, 2005; Yenilmez \& İşü̈den, 2007) çalışmaların yanı sıra işbirliğini (Akpınar \& Ergin, 2005; CantürkGünhan \& Başer, 2009b); iletişim (Budak, Budak, Tutak, \& Dane, 2009), araştırma (Uluyol, 2009) ve problem çözme becerilerini (İnce-Aka, Güven, \& Aydoğdu, 2010; İnel \& Balım, 2010) geliştirdiği de belirlenmiştir.

Norman ve Schmidt (1992), Haron ve Major (2004) öğrencilerin $\mathrm{P}_{\mathrm{b}} \mathrm{DÖ}$ 'ye yönelik görüşlerini araştırdıkları çalışmalarında sürecin öğrencilerin problem çözme, araştırma ve işbirliği becerilerini geliştirdiği sonucuna varmışlardır (akt. Demirel \&

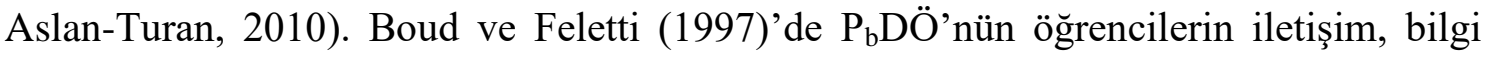
kaynaklarına ulaşma ve kullanabilme ve grupla çalışma becerilerini geliştirdiğini belirtmişlerdir (akt. Taşkesenligil, Şenocak \& Sözbilir, 2008). Hendry, Ryan ve Haris (2003) ile Chin ve Chia (2004) de benzer bulgulara ulaşmışlardır (akt. Akpınar \& Ergin, 2005). Shepherd (1998) yaptığı deneysel çalışmada $\mathrm{P}_{\mathrm{b}} \mathrm{DÖ}$ 'nün deney grubunda eleştirel düşünme becerisinin önemli ölçüde arttığını tespit etmiştir (akt. Thomas, 2000).

$\mathrm{P}_{\mathrm{b}} \mathrm{DÖ}$ yaklaşımının alan yazında çoğunlukla ortaokul, lise ve üzeri düzeylerde uygulanıp araştırıldığı görülmektedir. $\mathrm{P}_{\mathrm{b}} \mathrm{DÖ}$ yaklaşımının uygulama aşamalarının hassas bir sistematik gerektirmesi ve özellikle ilkokul düzeyinde yoğun bir öğretmen kılavuzluğuna ihtiyaç duyulması bu durumun gerekçeleri olarak kabul edilebilir; nitekim $\mathrm{P}_{\mathrm{b}} \mathrm{DÖ}$ yaklaşımının sınıf içi hareketliliğe tolerans gerektirmesi ve özellikle küçük yaş gruplarında öğretmen k1lavuzluğuna daha çok ihtiyaç duyulması, yöntemin sınırlılıkları olarak gösterilmektedir (Çetin, 2011; Kılınç, 2007). Buna karşın, yurt içi ve yurtdışı alan yazında ele alınan çalışmalarda, öğretmenlerin ve öğretmen adaylarının $\mathrm{P}_{\mathrm{b}} \mathrm{DÖ}$ yaklaşımının uygulanışına yönelik olumlu görüşlere sahip oldukları anlaşılmaktadır (Alagöz, 2011; Edwards \& Hammer, 2006; Kızılcık \& Tan, 2017; Yenilmez \& İşgüden, 2007).

$\mathrm{P}_{\mathrm{b}} \mathrm{DÖ}$ yaklaşımı öğrencileri işbirlikli çalışmaya yönlendirmesi, kendi görüş ve deneyimlerini grup içinde paylaşabilmeleri, keşfedilen bir problem durumunun çözüme kavuşturulabilmesi ve empati becerisini geliştirmesi açısından etkili bir yaklaşımdır. Gerek öğrencilerin akademik başarıları üzerindeki gerekse öğrenmeye yönelik tutumları üzerindeki olumlu etkilerinden hareketle $\mathrm{P}_{\mathrm{b}} \mathrm{DÖ}$ yaklaşımının çağdaş eğitim stratejileri arasında güçlü bir pozisyona sahip olduğu görülmektedir. $\mathrm{Bu}$ araştırmanın da $\mathrm{P}_{\mathrm{b}} \mathrm{DÖ}$ yaklaşımının uygulanışı bakımından ve ancak somut olaylar üzerinden empati kurmayı 
anlayabilmesi mümkün olabilecek ilkokul düzeyine odaklanması ile alan yazına katkı sağladığı ve araştırmacılara da $\mathrm{P}_{\mathrm{b}} \mathrm{DÖ}$ 'nün ilkokul düzeyinde uygulanabilirliği bakımından cesaret verebileceği düşünülmektedir.

\section{Öneriler}

Bu çalışmadan elde edilen bulgular ve ilgili alan yazın incelemelerinin ardından uygulayıcı ve araştırmacılara yönelik olarak şu önerilerde bulunulabilir:

- Empati becerilerinin geliştirilmesine yönelik olarak özellikle ilkokul düzeyinde programlar hazırlanabilir. Bu programların öğrencilerin iletişim becerileri, akademik başarıları ve okula yönelik tutumları üzerindeki etkileri araştırılabilir.

- $\mathrm{P}_{\mathrm{b}} \mathrm{DÖ} \mathrm{yaklaşımının} \mathrm{öğretim} \mathrm{programı} \mathrm{içeriğiyle} \mathrm{paralel} \mathrm{olarak} \mathrm{yürütülebilmesi}$ için program geliştirme süreçlerinde $\mathrm{P}_{\mathrm{b}} \mathrm{DÖ}$ yaklaşımının drama temelli olarak kullanımına böylece empati becerisinin gelişimine ağırlık verilebilir. 


\section{Summary}

Purpose and Significance: Empathy is a pro-social process directing towards an equal, just and cooperative living. Starting from early years of education, it is accepted that empathy has a critical value in order to improve humane interaction abilities which can be developed by means of various educational applications including drama, role playing etc. Problem-based learning (PBL) is one of those applications in which drama can be effectively applied. Regarding today's constructive understanding of educational approach, drama applications framed by a PBL approach could provide a very fertile ground to step forward in developing empathy skills. PBL is a learning model based on John Dewey's educational philosophy of learning as living. In this model, teachers act like providers of students' needs for construcing their solutions for a particular problem. In PBL, the problem must be thoroughly prepared by teachers and students must be moderated in small work-groups moving along seven basic principles.

The purpose of this study is to investigate the effects of PBL utilized with drama applications on primary school pupils' empathy skill levels. Regarding the basic principles of PBL, primary school is an advantegeous field to provide students with the ability to sense the main idea lying under the problem by using drama applications. In review of literature, it can be realized that limited research were made based on the effectiveness of PBL in social sciences. Except for those in secondary schools, no research can be found in primary school level about effectiveness of PBL in social sciences. Thus it is believed that this research could be beneficial both in recommending a new study program for developing empathy skills in primary education in social sciences and in providing an addition to educational literature for PBL.

Method: Pretest-posttest control-group design was utilized through the research which was applied on two groups each consisting of $243^{\text {rd }}$ graders. Data collection was conducted with "Scale of Empathy for Children". PBL process utilized with drama applications was conducted on experimental group and none on control group. Study plan for experimental group was prepared by two of researchers and applied for three weeks. Shapiro-Wilk normality test, independent-samples t-test and paired-samples ttest were used for data analysis.

Results: There were no significant differentiation between control and experimental groups regarding pre-test average scores. This finding shows that each group is identical as of scale pre-test scores. Regarding pre-test and post-test average scores of control and experimental groups, it was found that there were no significant differantions between pre-test and post-test average scores of control group. This finding shows that, after the 3 -week standart in-class program, average scores of control group did not differ. On the contrary, regarding pre-test and post-test average scores of experimental group, there was a significant differention between average scores.

Comparing post-test average scores of control and experimental groups, there was a significant differentiation between scores in favor of experimental group. This finding shows that the 3-week PBL program was effective in developing primary school pupils' empathy skill levels. 
Discussion and Conclusions: Findings gathered from the research bring forth that PBL program utilized with drama is more effective in developing primary school pupils' empathy skill levels than classical in-class applications like Q-A or lecturing in which students do not take part actively in learning processes.

Literature indicates that PBL is an effective way of learning especially in natural science education. Besides, it can be seen that students enjoy the process of problem solving and want to experince this in every part of their learning environments.

For such reasons that it requires a high level of moderation in low-age groups and a delicate balance between rigor and richness, it may be seen that research on PBL are widely applied in secondary schools, high schools or adult education. However, studies indicate that teachers have a significantly positive attitude for using PBL in educational applications.

PBL is an effective way of learning for directing and motivating children to study in work-groups, share their experiences, make research and question their own stances against problematic situations. It has a highly powerful effect on both academic success and attitudes for learning in general. If concentrated on primary school students and social science education, it may take a strong position in today's educational strategies. 


\section{Kaynakça}

Adıgüzel, Ö. (2018). Eğitimde yaratıcı drama. İstanbul: Yapı Kredi Yayınları.

Akpınar, E., \& Ergin, Ö. (2005). Probleme dayalı öğrenme yaklaşımına yönelik öğrenci görüşleri. İnönü Üniversitesi Eğitim Fakültesi Dergisi, 6(9), 3-14.

Akpınar, B., \& Özdaş, F. (2013). İlköğretimde değerler eğitimine ilişkin öğretmen görüşleri: nitel bir analiz. Fırat Üniversitesi Sosyal Bilimler Dergisi, 23(2), 105113.

Akınoğlu, O., \& Tandoğan, R. Ö. (2007). The effects of problem-based active learning in science education on students' academic achievement, attitude and concept learning. Eurasia Journal of Mathematics, Science \& Technology Education, 3(1), 71-81.

Alagöz, B. (2011). Probleme dayalı öğrenme yönteminin sosyal bilgiler öğretmen adayları üzerindeki etkisi. Milli Eğitim Dergisi, 41(190), 167-186.

Ampuero, D. A., Miranda, C., \& Goyen, S. (2015). Positive psychology in education for sustainable development at a primary-education institution. Local Environment, 20(7), 745-763.

Andersen, C. (2004). Learning in "As-If" Worlds: Cognition in Drama in Education. Developmental Psychology: Implications for Teaching (Autumn, 2004), 281-286.

Aykaç, N. (2005). Aktif ögretim yöntemleri. Ankara: Naturel Kitap.

Balc1, A. (2010). Sosyal bilimlerde araştırma yöntem, teknik ve ilkeler. Ankara: Pegem Akademi.

Baysal, Z. N. (2005). Hayat bilgisi/sosyal bilgiler öğretiminde probleme dayalı öğrenme için problem durumları oluşturma. Türk Eğitim Bilimleri Dergisi, 3(4), 471-485.

Baysal, Z. N., Duman, M., Arkan, K., \& Hastürk, E. (2012). Probleme dayalı öğrenme yaklaşımının öğrencilerin görsel sunu ve yazma eğilimlerine etkisi. Uluslararası Ĕ̈itim Programları ve Öğretim Çalışmaları Dergisi, 2(4), 78-90.

Borrows, H. S. (1996). Problem-based learning in medicine and beyond: A brief overview. New Directions for Teaching and Learning, 68, 3-12.

Bryant, B. (1982). An index of empathy for children and adolescents. Child Development, 53(2), 413-425.

Budak, İ., Budak, A., Tutak, T., \& Dane, A. (2009). "Matematikte düz anlatım ve problem çözme sınıflarındaki öğretmen-öğrenci etkileşim farklılıklarının karşılaştırılması". Erzincan Üniversitesi Ĕ̆itim Fakültesi Dergisi, 26, 180-189.

Büyüköztürk, Ş. (2012). Sosyal bilimler için veri analizi el kitabı. Ankara: Pegem Akademi.

Büyüköztürk, Ş., Çokluk, Ö., \& Köklü, N. (2011). Sosyal bilimler için istatistik. Ankara: Pegem Akademi.

Cantürk-Günhan, B., \& Başer, N. (2008). Probleme dayalı öğrenme yöteminin öğrencilerin matematiğe yönelik tutumlarına ve başarılarına etkisi. Abant İzzet Baysal Üniversitesi Ĕ̈itim Fakültesi Dergisi, 8(1), 119-134.

Cantürk-Günhan, B., \& Başer, N. (2009a). Probleme dayalı öğrenmeye ilişsin öğrenci, öğretmen ve öğretim üyelerinin görüşleri. Necatibey Eğitim Fakültesi Elektronik Fen ve Matematik Eğitimi Dergisi, 3(1), 134-155. 
Cantürk-Günhan, B., \& Başer, N. (2009b). Probleme dayalı öğrenmenin öğrencilerin eleştirel düşünme becerilerine etkisi. Türk Eğitim Bilimleri Dergisi, 7(2), 451-482.

Catterall, J. S. (2007). Enhancing peer conflict resolution skills through drama: an experimental study. Research in Drama Education: The Journal of Applied Theatre and Performance, 12(2), 163-178.

Curtis, D., Howden, M., Curtis, F., McColm, I., Scrine, J., Blomfield, T., . . Ryan, T. (2013). Drama and Environment: Joining Forces to Engage Children and Young People in Environmental Education. Australian Journal of Environmental Education, 29(2), 182-201.

Çetin, Ş. (2011). Probleme dayalı öğrenme. (Ed. S. B. Filiz), Öğrenme Öğretme Kuram ve Yaklaşımları içinde (s. 234-248). Ankara: Pegem Akademi.

Çiftçi, S., Meydan, A., \& Ektem, I. S. (2007). Sosyal bilgiler öğretiminde probleme dayalı öğrenmeyi kullanmanın öğrencilerin başarısına ve tutumlarına etkisi. Selçuk Üniversitesi Sosyal Bilimler Enstitüsü Dergisi, 1(17), 161-178.

Demirel, M., \& Arslan-Turan, B. (2010). Probleme dayalı öğrenmenin başarıya, tutuma, bilişötesi farkındalık ve güdü düzeyine etkisi. Hacettepe Üniversitesi Ĕgitim Fakültesi Dergisi, 38, 55-66.

Edwards, S., \& Hammer, M. (2006). Laura's story: Using Problem Based Learning in early childhood and primary teacher education. Teaching and Teacher Education, 22(4), 465-477.

Feshbach, N. D., \& Feshbach, S. (2009). Empathy and education. (J. D. Ickes), The Social Neuroscience of Empathy içinde (pp. 85-99). Massachusetts: The MIT Press.

Freeman, G., Sullivan, K., \& Fulton, C. (2003). Effects of creative drama on selfconcept, social skills, and problem behavior. The Journal of Educational Research, 96(3), 131-138.

Gijselaers, W. (1995). Perspectives on problem-based learning. In W. H. Gijselaers, D. T. Tempelaar, P. K. Keizer, J. M. Blommaert, E. M. Bernard, \& H. Kasper (Eds.), Educational innovation in economics and business administration: The case of problem-based learning (pp. 39-52). Netherlands: Kluwer Academic Publishers.

Good, J. S., Fox, J., \& Coffen, R. (2011). Fostering the development of empathy in the classroom: A strategic response to the problem of bullying. Teaching \& Professional Practice, 5(1), 24-30.

Hicks, J. F., Le Clair, B., \& Berry, S. (2016). Using solution-focused dramatic empathy training to eliminate cyber-bullying, Journal of Creativity in Mental Health, 11:3-4, 378-390.

Hmelo-Silver, C. E. (2004). Problem-Based learning: what and how do students learn? Educational Psychology Review, 16(3), 235-266.

Ilgın, H., \& Arslan, D. (2012). Türkçe dersinde metinlerle problem çözme öğretiminin öğrencilerin problem çözme becerilerine etkisi. Ahi Evran Üniversitesi Kırşehir Ĕ̌itim Fakültesi Dergisi, 13(2), 157-176.

İnan, H. Z. (2005). Okullarda çocuklar arası zorbalık. M. ̈. Atatürk Eğitim Fakültesi Ĕ̈itim Bilimleri Dergisi, 22, 161-170. 
İnce-Aka, E., Güven, E., \& Aydoğdu, M. (2010). Effect of problem solving method on science process skills and academic achievement. Journal of Turkish Science Education, 7(4), 13-25.

İnel, D., \& Balım, A. G. (2010). "Fen ve teknoloji öğretiminde probleme dayalı öğrenme yöntemi kullanımına ilişkin öğrenci görüşleri”. Batı Anadolu Eğitim Bilimleri Dergisi, 1(1), 1-13

Kabapınar, Y. (2012). Ötekinin penceresinden duruma bakmanın aracı ve bir öğretim yöntemi olarak empati. (Ed. C. Öztürk), Sosyal Bilgiler Öğretimi içinde (ss. 284293). Ankara: Pegem Akademi.

Kabapınar, Y., Canpolat, Y., Yarar, N., \& Karaday1, S. (2016). Hayat bilgisi dersinde sosyal empati etkinliklerini uygulamak: ötekini duyumsayarak var oluyorum. Abant İzzet Baysal Üniversitesi Ĕgitim Fakültesi Dergisi, 16(USBES Özel Sayı II), 13201338.

Kalliopuska, M. (1992). Holistic empathy education among preschool and school children. International Scientific Conference Comenius' Heritage and Education of Man (pp. 23-27). Prag: ERIC.

Kaptan, F., \& Korkmaz, H. (2001). Fen eğitiminde probleme dayalı öğrenme yaklaşımı. Hacettepe Üniversitesi Ĕ̌itim Fakültesi Dergisi, 20, 185-192.

Karakuş, U. (2006). Probleme dayalı öğrenme yaklaşımının sosyal bilgiler derslerinde uygulanması. Ahi Evran Üniversitesi Kırşehir Eğitim Fakültesi Dergisi, 7(2), 163 176.

Karasar, N. (2011). Bilimsel araştırma yöntemi. Ankara: Nobel Yayıncılık.

Kasapoğlu, H., \& Güneysu, S. (2017). Öğrencilerin duygusal zeka becerilerinin geliştirilmesinde yaratıcı dramanın kullanılmasına ilişkin görüşlerin incelemesi. Kastamonu Ë̆itim Dergisi, 25(3), 1039-1054.

Keski, Y., \& Aykaç, M. (2014). İletişim engellerinin aile içi iletişime etkisini incelemede yaratıcı drama yönteminin kullanımına ilişkin katılımcı görüşleri. Türkiye Sosyal Araştırmalar Dergisi 18(3), 121-144.

Kılınç, A. (2007). Probleme dayalı öğrenme. Kastamonu Eğitim Dergisi, 15(2), 561578.

Kızılcık, H. Ş., \& Tan, M. (2017). Probleme dayalı öğrenme sürecinin öğretmen adayları tarafından değerlendirilmesi. Gazi Eğitim Bilimleri Dergisi, 3(1), 1-16.

Kohlberg, L. (1975). Moral education for a society in moral transition. Educational Leadership, 33, 46-54.

Kosti, K., Kondoiyanni, A., \& Tsiaras, A. (2015). Fostering historical empathy through drama-in-education: a pilot study on secondary school students in greece. Drama Research, 6(1), 2-15.

Kuštrin, I. (2005). Problem design. (V. Jurković), Guide to Problem-Based Learning içinde (ss. 8-12). Ljubljana, Slovenia: Association of LSP Teachers.

McNaughton, M. J. (2006). Learning from participants' responses in educational drama in the teaching of education for sustainable development. Research in Drama Education. The Journal of Applied Theatre and Performance, 11(1), 19-41. 
Mehrabian, A., \& Epstein, N. (1972). A measure of emotional empathy. Journal of Personality, 40, 525-543.

Nagy, P., Laskey, A., \& Allison, P. (1993). Evaluation as harvesting: Drama in education as tender fruit. Canadian Journal of Education / Revue Canadienne De L'éducation, 18(2), 117-131.

Nicoll, K., Trifone, C., \& Samuels, W. E. (2008). An in-class, humane education program can improve young students' attitudes toward animals. Society and Animals, 16(1), 45-60.

O’Toole, J. (2002). Drama: The productive pedagogy. Melbourne Studies in Education, $43,39-52$.

Önalan-Akfirat, F. (2006). Sosyal yeterlilik, sosyal beceri ve yaratıcı drama. Yaratıcı Drama Dergisi, 1(1), 39-58.

Roth-Hanania, R., Davidov, M., \& Zahn-Waxler, C. (2011). Empathy development from 8 to 16 months: Early signs of concern for others. Infant Behavior and Development, 34(3), 447-458.

Salı, G. (2012). İlköğretim ikinci kademedeki çocukların empatik eğilimlerinin ve benlik kavramlarının incelenmesi. Kuramsal Eğitimbilim Dergisi, 6(4), 496-519.

San, İ. (2006). Tiyatroya rağmen yaratıcı drama. Yaratıcı Drama Dergisi, 1(1).5-15.

Savery, J. R. (2006). Overview of problem-based learning: definitions and distinctions. The Interdisciplinary Journal of Problem-based Learning, 1(1), 9-20.

Schmidt, H. G. (1983). Problem-based learning: rationale and description. Medical Education, 17(1), 11-16.

Schultz, N., \& Christensen, H. P. (2004). Seven-step problem-based learning in an interaction design course. European Journal of Engineering Education, 29(4), 533541.

Siyez, D. M., \& Kaya, A. (2011). Akran zorbalığı gruplarında empatik eğilim. İnönü Üniversitesi Ĕ̈itim Fakültesi Dergisi, 12(2), 23-43.

Şahin, M. (2012). An investigation into the efficiency of empathy training program on preventing bullying in primary schools. Children and Youth Services Review, 34, 1325-1330.

Uluyol, Ç. (2009). Problem temelli öğrenmenin öğrenci başarısına etkisi ve öğrenci görüşlerinin değerlendirilmesi. Gazi Üniversitesi Eğitim Fakültesi Dergisi, 29(1), 19-36.

T.C. Millî Eğitim Bakanlığı Talim ve Terbiye Kurulu Başkanlığı. (2009). İlköğretim 1, 2 ve 3. Sınıflar Hayat Bilgisi Dersi Öğretim Programı ve Kılavuzu. Ankara. 5 13, 2018 tarihinde http://talimterbiye.mebnet.net/Ogretim\%20Programlari/ilkokul/20102011/HayatBilgisi-3.Sınıf.pdf adresinden alındı

Taşkesenligil, Y., Şenocak, E., \& Sözbilir, M. (2008). Probleme dayalı öğrenme teorik temelleri. Milli Ĕ̈itim Dergisi, 177, 50-58.

Thomas, J. W. (2000). A review of research on project-based learning. http://www. Rinet/middletown/mef/linkresources/documents/researchreviewPBL_070226.pdf adresinden 29.06.2009 tarihinde alınmıştır. 
Ülger, K. (2012). Görsel sanatlar eğitiminde probleme dayalı öğrenme yönteminin öğrencilerin problem çözme becerilerine etkisi. Milli Ĕ̆itim Dergisi, 195, 23-42.

Ülger, K., \& İmer, Z. (2013). Probleme dayalı öğrenme yaklaşımının (pdö) öğrencilerin yaratıcı düşünme becerileri üzerine etkisi. Hacettepe Üniversitesi Eğitim Fakültesi Dergisi, 28(1), 382-392.

Üstündağ, T. (1998). Yaratıcı drama eğitim programının öğeleri. Eğitim ve Bilim/Education and Science, 22(107), 28 -35.

Verducci, S. (2000). A Conceptual history of empathy and a question raises for moral education. Educational Theory, 50(1), 63-80.

Yaman, S., \& Yalçın, N. (2005). Fen bilgisi öğretiminde probleme dayalı öğrenme yaklaşımının yaratıcı düşünme becerisine etkisi. İlköğretim Online, 4(1), 42-52.

Yaşar, Ş., \& Gültekin, M. (2012). Anlamlı öğrenme için etkili öğretim stratejileri. (Ed. C. Öztürk), Sosyal Bilgiler Öğretimi içinde (ss. 77-109). Ankara: Pegem Akademi.

Yenilmez, K., \& İşgüden, E. (2007). Probleme dayalı matematik öğretimine yönelik öğretmen görüşleri. İnönü Üniversitesi Eğitim Fakültesi Dergisi, 7(13), 119-131.

Yüksel, A. (2004). Empati eğitim programının ilköğretim öğrencilerinin empatik becerilerine etkisi. Uludă̆ Üniversitesi Eğitim Fakültesi Dergisi, 12(2), 341-354.

Yüksel, A. (2009). İlköğretim 5. sınıf öğrencilerinin empatik becerileriyle aile işlevleri ve benlik kavramları arasındaki ilişkinin incelenmesi. Pamukkale Üniversitesi Ĕ̈itim Fakültesi Dergisi, 1(25), 153-165. 